\title{
The growth of Shorea leprosula at various planting distances and slopes in Gunung Dahu Research Forest, Bogor, Indonesia
}

\author{
PRIJANTO PAMOENGKAS ${ }^{1, \boldsymbol{v}}$, HENTI H. RACHMAT ${ }^{2}$, NADYA KHALIFA ${ }^{1}$ \\ ${ }^{1}$ Department of Silviculture, Faculty of Forestry and Environment, Institut Pertanian Bogor. Jl. Ulin, IPB Campus Dramaga, Bogor 16680, West Java, \\ Indonesia. Tel./fax.:+62-251-862-6806,`email: ppam@apps.ipb.ac.id; prijantop@yahoo.com \\ ${ }^{2}$ Forest Research, Development and Innovation, Ministry of Environment and Forestry. Jl. Raya Gunung Batu No. 5, Bogor 16610, West Java, Indonesia
}

Manuscript received: 16 August 2020. Revision accepted: 29 August 2020.

\begin{abstract}
Pamoengkas P, Rachmat HH, Khalifa N. 2020. The growth of Shorea leprosula at various planting distances and slopes in Gunung Dahu Research Forest, Bogor, Indonesia. Biodiversitas 21: 4396-4404. Shorea leprosula Miq. is one of the species of Dipterocarpaceae family which has great potential to be developed as plantation forestry. This research aimed to investigate the effect of planting distance and slope on the growth of S. leprosula in Gunung Dahu Research Forest, Bogor, Indonesia. Growth variables in terms of height and diameter, and environmental factors were observed in S. leprosula stands at various planting distances and slopes. Analysis results showed that plot with planting distance of $4 \times 6 \mathrm{~m}$ produced the best growth of $S$. leprosula than other planting distances, with the largest increment of diameter and height of $1.49 \mathrm{~cm} /$ year and $0.82 \mathrm{~m} /$ year, respectively. Slope class did not affect the diameter growth, but it affected the height growth. Slope class flat (0-8\%) exhibited height growth of $S$. leprosula of $0.81 \mathrm{~cm} / \mathrm{year}$, which was better compared to other slope classes. Interaction between planting distance of 4x6 m and slope class of rather steep (15-25\%) produced the best growth of $S$. leprosula compared to other interactions with diameter and height increment of $1.64 \mathrm{~cm} / \mathrm{year}$ and $0.83 \mathrm{~m} / \mathrm{year}$, respectively.
\end{abstract}

Keywords: Gunung Dahu Research Forest, growth, planting distance, Shorea leprosula, slope class

\section{INTRODUCTION}

Rehabilitation of degraded forests and lands is a most urgent matter requiring increased productivity of ecosystems to satisfy human aim. In the forestry sector, the implementation of forest rehabilitation and restoration is included in Sustainable Development Goals 15 (SDG 15), namely "Protecting, restoring and enhancing the sustainable use of terrestrial ecosystems, managing forests sustainably, stopping desertification, restoring land degradation, and stopping the loss of biodiversity." (Baumgartner 2019). Data from the Directorate General of Forestry Planning and Environmental Management (PKTL), Ministry of Environment and Forestry, showed that Indonesia's deforestation trend is relatively lower, and tends to be stable. Data on deforestation in 2018-2019 occurred both inside and outside of forest areas approximately 462.400 ha. The highest deforestation area occurred in the secondary forest, round about 162.800 ha, about $55.7 \%$ of the data or 90.600 ha were inside the forest area and the remaining 72.200 ha, or $44.3 \%$ were outside of the forested area (KHLK 2020a). In Indonesia, starting in 2019 the Ministry of Environment and Forestry has taken a number of corrective steps, including the target area of Forest and Land Rehabilitation to be 207.000 ha which covers of inside and outside of forest areas, including peat ecosystems, upland landslides, and floods, and restoration of forest and land fires (KLHK 2020b).

In the condition where very little or none of the natural ecosystem remains, plantation or site management should be considered. Tree species planted on a large scale generally can quickly form a single species. They regularly produce a large amount of seeds and have a short life span. They also have plasticity for edaphic, microclimatic, and biotic conditions. Many fast-growing and commercial tree species used now for forest plantations have these characteristics. On the other hand, many dipterocarps have the opposite characteristics, such as irregular fruiting, shade demanding, slow-growing in the early growth stages, and a long life span. Many dipterocarps require mild environmental conditions in their early growth stages because more than half of the species inhabit humid rain forest that has a narrow range of temperature and humidity fluctuations and the young trees live in partially shaded conditions throughout the year. The key technology for rehabilitation using dipterocarp species is light control and species choice.

One of native tree species promising for forest rehabilitation is Shorea leprosula Miq.. This species belongs to the family of Dipterocarpaceae and is classified as red meranti group, a group of dipterocarps that constitutes tree species that grow fast with high increment in height, that it has great potential to be developed for plantation forestry (Soekotjo 2009). In addition, $S$. leprosula is one of commercial timber species that has economic value with high selling price because its wood is favored by wood processing industry (Wistara et al. 2016). When developing plantation forestry using native tree species such as S. leprosula, the success of planting is one of key aspects to achieve sustainable forest management. 
The planting success can be represented by various factors, one of which is plant growth in terms of height and diameter. In plantation management, planting distance plays important roles that affect plant growth rate, wood quality and cutting cyclel, and economic aspect of the investment (Magalhães et al. 2007). There is a strong relationship between tree individual growth and growing space which explains growth form at various statuses within a stand (Gersonde and O'Hara 2005).

Beside planting distance, Adam and Kolbs (2005) explained that differences in growth patterns within similar species in the same location could be largely influenced by environmental factors. Environmental factor which can affect plant growth, is among others, topographic factor, namely slope. Slope constitutes one of the indirect environmental factors which could affect plant growth through erosion process in soil surface, which could degrade soil as plant growth media (Schmidt et al. 2019). Therefore, this research aimed to investigate the effect of planting distance and slope on the growth of $S$. leprosula. While there were several previous studies of similar theme (Adjers et al. 1995; Tirkaamania et al.2019; Mawazin and Suhendi 2012; Purnomo et al. 2013), this study was conducted in different context, i.e. the location of the study in Gunung Dahu Research Forest, so that the results can enrich the existing knowledge on the silvicultural aspect of S. leprosula. Gunung Dahu Research Forest is one of the research forests managed by the Forest Research, Development and Innovation under the Indonesian Ministry of Environment and Forestry. The forest was previously a marginal land before planted with several species of Shorea and regenerated naturally without any maintenance activities. The planting trials of
Dipterocarpaceae species in Gunung Dahu showed successful results, providing insight that Dipterocarpaceae species can be developed for plantation forestry.

\section{MATERIALS AND METHODS}

\section{Study area and period}

This research was conducted in Gunung Dahu Research Forest from October to December 2019. Geographically, Gunung Dahu Research Forest (GDRF) is located at S 06³6'30" - 06 $37^{\circ} 00^{\prime \prime}$ and E 106³4'00" - 106 35'30". Administratively, the area of Gunung Dahu Research is located in Pabangbon Village, Leuwiliang Subdistrict, Bogor District, West Java Province, Indonesia. The area receives rainfall of $2500-2700 \mathrm{~mm} /$ year. It is situated at elevation of 550-900 m asl with hilly and steep topography. It has soil type of Reddish Brown Latosol (KLHK 2013). The climate type Gunung Dahu belongs to type B with relative humidity of $80 \%$ and average temperature of $30^{\circ} \mathrm{C}$ (Leksono 2010).

Data collection was conducted at the stands of $S$. leprosula occurring in plots $1,2,6,7$, and 22 , where the size of each plot was $100 \mathrm{~m} \times 100 \mathrm{~m}$ (1 ha). The stand of $S$. leprosula in each plot was planted with technique of total planting with planting distance of $2 \times 2 \mathrm{~m}$ in plots $1,3 \times 3$ $\mathrm{m}$ in plots 2 and 22, and planting distance of $4 \times 6 \mathrm{~m}$ in plots 6 and 7. Each plot was then divided into five slope classes, namely $0-8 \%$ (flat), 8-15\% (slightly sloping), 15$25 \%$ (rather steep), $25-40 \%$ (steep) and $>45 \%$ (very steep). The observation sites of $S$. leprosula being planted in the experimental blocks are shown in Figure 1.
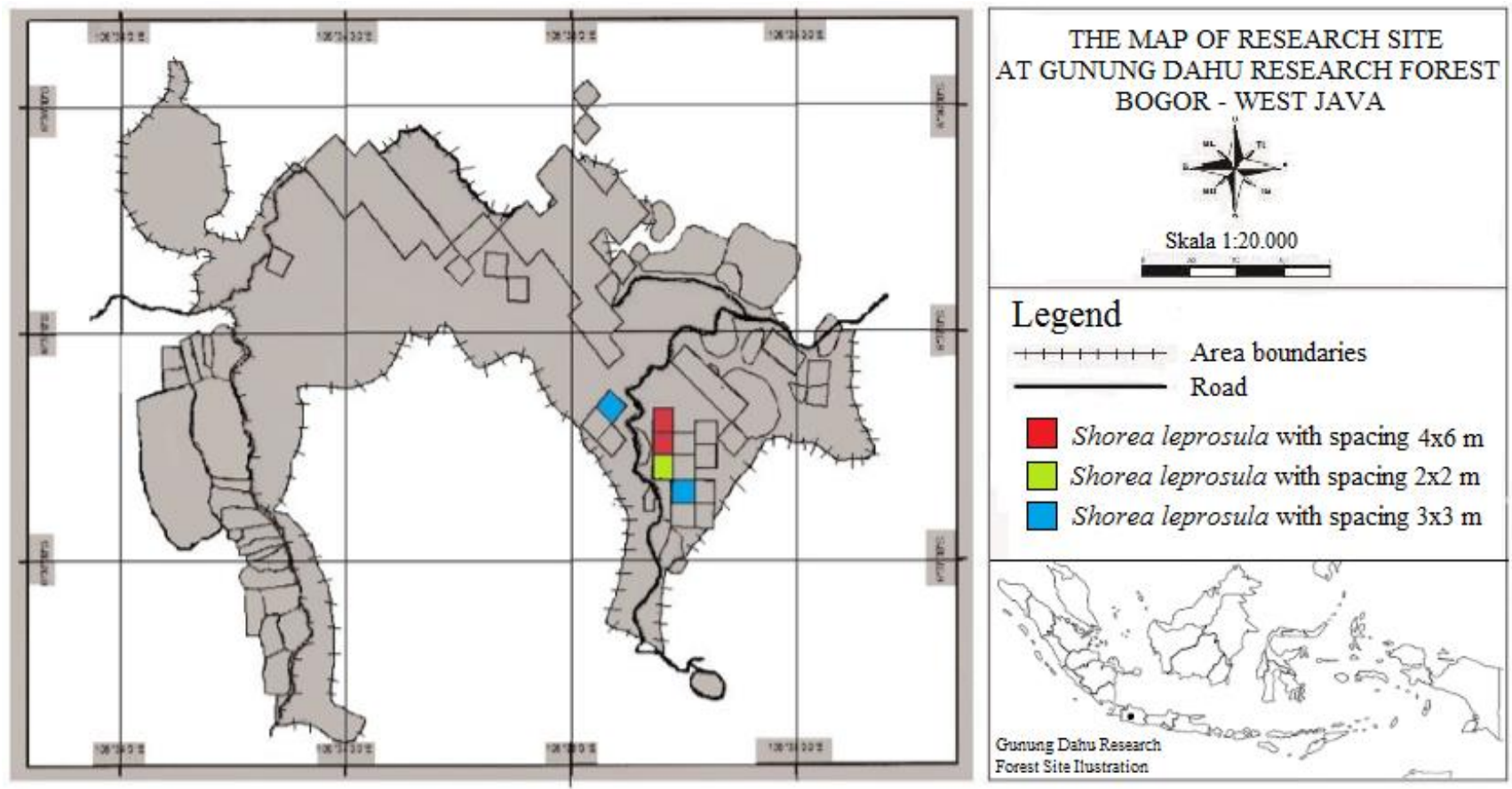

Figure 1. Map of Gunung Dahu Research Forest, Bogor, West Java, Indonesia and plots of data collection 


\section{Data collection}

Data needed in this research comprised primary data and secondary data. Primary data comprised diameter (DBH) and total height of tree, coordinates, and elevation of each plot, crown cover, and the environmental conditions of the growth site (i.e. soil texture, litter thickness, and topsoil thickness). The measurements of height and diameter growth of S. leprosula were conducted in each observation plot. On the other hand, secondary data were in the form of general description of the research location, map of research location and other data related to this research. Research procedure comprised plot determination, data collection in the field, data distribution, and analysis of data from field observation.

\section{Data analysis}

We analyzed the data to investigate the effect of various slope classes and planting distances on the growth of $S$. leprosula. Data analysis was conducted by calculating: (i) Average height and diameter; (ii) Annual Average Increment (AAI) of diameter and height; (iii) Data distribution; (iv) Stand Density; (v) Crown Cover; and (vi) ANOVA test and Duncan advanced test.

\section{Calculation of average height and diameter}

Tree trunk diameter was measured using a plastic meter at a point as high as $1.30 \mathrm{~m}$ or diameter at breast height, while tree height was measured using a Haga hypsometer. The calculation used the following formula:

Average tree height $=\frac{\text { Stree height }[\mathrm{m} \text { ) }}{\text { N total number of trees }}$

Average tree diameter $=\frac{\sum \text { tree diameter }[\mathrm{cm}]}{\text { Ntotal number of trees }}$

Annual Average Increment (AAI) of diameter and height of tree

Increment is defined as the increase in tree dimensions (e.g. diameter or height) or stands volume per unit of time (e.g. year) (Davis dan Jhonson 1987). Annual Average Increment (AAI) was calculated using the following formula:

$$
\begin{aligned}
& \mathrm{I} h i=\frac{\mathrm{hi}}{\mathrm{ti}} ; \mathrm{I} d i=\frac{d \mathrm{di}}{\mathrm{ti}} \\
& \text { Where: } \\
& \text { Idi : average diameter at } \mathrm{i}^{\text {th }} \text { year }(\mathrm{cm} / \text { year) } \\
& \text { Ihi }: \text { average height at } \mathrm{i}^{\text {th }} \text { year }(\mathrm{m} / \text { year }) \\
& \text { di : average diameter at } \mathrm{i}^{\text {th }} \text { planting year }(\mathrm{cm}) \\
& \text { hi }: \text { average height at } \mathrm{i}^{\text {th }} \text { planting year }(\mathrm{m}) \\
& \text { ti } \quad \text { plant age at } \mathrm{I}^{\text {th }} \text { planting year (year) }
\end{aligned}
$$

\section{Data distribution}

Data distribution in this research was analyzed using boxplot to investigate the characteristics and distribution of the data. Distance between parts of the box shows the degree of distribution and skewness within the data. On the other hand, whiskers show the values which are lower and higher than group of data occurring inside the box (except for the outlier) (Nugraheni 2012).

\section{Crown cover}

Crown cover was measured as Leaf Area Index (LAI). LAI is one of the parameters of plant growth which examines the extent to which the ground surface is covered by leaves or canopy (Kafabih 2017). LAI data was collected using hemispherical canopy photograph by applying fish-eye lens placed under tree cover. Taking the photograph of tree crown was conducted at 5 points in each plot, measuring 1 ha each. The photograph of tree crowns that had been obtained was then analyzed using Hemiview application to obtain the LAI values. The values of LAI obtained from the five points from each plot were then being averaged to obtain the LAI value for each plot.

\section{Stand density}

Tree density shows the number and distribution of tree individuals in a particular area with particular size. Density of a species is a value that shows the number of individuals of a species per unit area. The higher the tree density, the greater the number of individuals of such species per unit area. The calculation of stand density used the following formula :

$$
\text { Stand density (trees } / \text { hectare) }=\frac{\text { Number of trees in the plot }}{\text { Area size of plot in hectare }}
$$

\section{ANOVA and Duncan advanced test}

Analysis of Variance (ANOVA) was used to investigate the effect of various planting distances and various slope classes on the growth of S. leprosula. If the P-value $>\alpha$ $(0.05)$, there was no effect of treatments (i.e. slope class, planting distance, and interaction between slope class and planting distance) on the growth parameters (i.e. diameter and total height) of S. leprosula. In contrast, if the P-value $<\alpha(0.05)$, treatments had significant effect on the growth parameters of $S$. leprosula. If the ANOVA results showed significant effects of the treatments, then Duncan advanced test was conducted. The statistical analyses were performed using IBM SPSS Statistics 25.

\section{RESULTS AND DISCUSSION}

\section{Description of Shorea leprosula stands}

Shorea leprosula is one species of the family of Dipterocarpaceae planted in the experimental plot in Gunung Dahu Research Forest. In this study, each observation plot had an extent of 1 hectare. All the stands within the observation plots were planted in 1997 using cutting method. Plant growth is affected by environmental conditions, such as soil texture, topsoil thickness and litter thickness, and LAI (Leaf Area Index). Information about environmental conditions at each research plot of $S$. leprosula stand is presented in Table 1. Plant growth is affected by environmental conditions, such as soil texture, topsoil thickness and litter thickness, and LAI (Leaf Area Index). Environmental conditions of each plot can be seen in Table 1. 
Table 1. Information of research plots of Shorea leprosula stand and the environmental conditions of research plot of S. leprosula stand in Gunung Dahu Research Forest, Bogor, West Java, Indonesia

\begin{tabular}{lccccccc}
\hline $\begin{array}{c}\text { Plot } \\
\text { number }\end{array}$ & $\begin{array}{c}\text { Planting } \\
\text { distance }\end{array}$ & $\begin{array}{c}\text { Elevation } \\
\text { (m asl) }\end{array}$ & $\begin{array}{c}\text { Soil } \\
\text { texture }\end{array}$ & $\begin{array}{c}\text { Topsoil } \\
\text { thickness (cm) }\end{array}$ & $\begin{array}{c}\text { Average litter } \\
\text { thickness (cm) }\end{array}$ & $\begin{array}{c}\text { Stand density } \\
\text { (ind/ha) }\end{array}$ & LAI \\
\hline 1 & $2 \times 2 \mathrm{~m} 2$ & 713 & Clay & 17 & 4.94 & 1137 & 1.58 \\
2 & $3 \times 3 \mathrm{~m} 2$ & 715 & Clay & 42 & 4.60 & 382 & 1.28 \\
22 & $3 \times 3 \mathrm{~m} 2$ & 777 & Clay & 50 & 7.10 & 225 & 1.35 \\
6 & $4 \times 6 \mathrm{~m} 2$ & 719 & Clay & 12 & 6.08 & 216 & 1.41 \\
7 & $4 \times 6 \mathrm{~m} 2$ & 726 & Clay & 47 & 11.60 & 118 & 1.32 \\
\hline
\end{tabular}

Table 2. The growth of Shorea leprosula stand in Gunung Dahu Research Forest, Bogor, West Java, Indonesia at various planting distances and slopes

\begin{tabular}{|c|c|c|c|c|c|c|}
\hline \multirow[b]{2}{*}{ No } & \multirow{2}{*}{$\begin{array}{l}\text { Planting } \\
\text { distance }\end{array}$} & \multirow{2}{*}{$\begin{array}{l}\text { Slope } \\
\text { class }\end{array}$} & \multicolumn{2}{|c|}{ Average } & \multicolumn{2}{|c|}{ Increment (MAI) } \\
\hline & & & $\begin{array}{l}\text { Diameter } \\
\text { (cm) }\end{array}$ & $\begin{array}{l}\text { Total height } \\
\text { (m) }\end{array}$ & $\begin{array}{l}\text { Diameter } \\
\text { (cm/year) }\end{array}$ & $\begin{array}{c}\text { Height } \\
\text { (m/Year) }\end{array}$ \\
\hline \multirow[t]{5}{*}{1} & $2 \times 2 \mathrm{~m}$ & Flat & 19.42 & 18.13 & 0.88 & 0.82 \\
\hline & & Slightly sloping & $14.47 *$ & $13.81 *$ & $0.66^{*}$ & $0.63^{*}$ \\
\hline & & Rather steep & 16.46 & 17.50 & 0.75 & 0.80 \\
\hline & & Steep & 18.48 & 15.35 & 0.84 & 0.70 \\
\hline & & Very Steep & 19.80 & 17.10 & 0.90 & 0.78 \\
\hline \multirow[t]{5}{*}{2} & $3 \times 3 \mathrm{~m}$ & Flat & 27.36 & 16.38 & 1.24 & 0.74 \\
\hline & & Slightly sloping & 23.38 & 13.91 & 1.06 & 0.64 \\
\hline & & Rather steep & 22.11 & 15.96 & 1.01 & 0.73 \\
\hline & & Steep & 22.40 & 15.83 & 1.02 & 0.72 \\
\hline & & Very Steep & 22.91 & 14.15 & 1.04 & 0.64 \\
\hline \multirow[t]{5}{*}{3} & $4 \times 6 \mathrm{~m}$ & Flat & 33.85 & 17.72 & 1.54 & 0.81 \\
\hline & & Slightly sloping & 31.27 & 17.81 & 1.42 & 0.81 \\
\hline & & Rather steep & $35.99 * *$ & 18.16 & $1.64 * *$ & 0.83 \\
\hline & & Steep & 32.29 & $18.56 * *$ & 1.47 & $0.84 * *$ \\
\hline & & Very Steep & 30.07 & 16.84 & 1.37 & 0.77 \\
\hline
\end{tabular}

Note: *Expressing minimum value; **Expressing maximum value

\section{Growth of diameter and height of Shorea leprosula}

Plant growth is a process of dimensional increase of a plant, resembling the yield of such plant. The results of observation and measurement of height and diameter of $S$. leprosula at various planting distances are presented in Table 2.

The results showed that the highest diameter growth occurred in S. leprosula stand with planting distance of $4 \times 6$ $\mathrm{m}$ and slope class of rather steep $(15-<25 \%)$ with average diameter of $35.99 \mathrm{~cm}$ and diameter MAI of $1.64 \mathrm{~cm} /$ year (Table 2). The lowest growth in diameter occurred in $S$. leprosula stand with planting distance of $2 \times 2 \mathrm{~m}$ and slope class of slightly sloping (8-15\%) with average diameter of $14.47 \mathrm{~cm}$ and MAI of diameter of $0.66 \mathrm{~cm} /$ year.

The results in Table 2 suggest that the larger is the planting distance, the higher is the average diameter (i.e. $4 \times 6 \mathrm{~m}>3 \times 3 \mathrm{~m}>2 \times 2 \mathrm{~m}$ ). This finding is in accordance with the research by Subiakto et al. (2016) concerning choice of local species for development of man-made forest, reported that average diameters of S. leprosula planted in Gunung Dahu Research Forest, ranked from the highest to the lowest were consecutively at the following planting distances: $4 \times 4 \mathrm{~m}>3 \times 3 \mathrm{~m}>2 \times 2 \mathrm{~m}$. The high average diameter at the planting distance of $4 \times 6 \mathrm{~m}$ and the low average diameter at planting distance of $2 \times 2 \mathrm{~m}$ is likely caused that denser population in a stand could increase competition between individuals due to limited nutrition, light, and water. According to Mawazin and Suhaendi (2012), different application of planting distances will create different light intensities which affect plant growth. The higher the population of plants per unit of area, the greater will be competition for water, nutrient element, and light among individuals, so that plant growth will be disturbed and plant yield will decrease.

On the other hand, the highest height growth occurred in S. leprosula stand with planting distance of $4 \times 6 \mathrm{~m}$ and slope class of steep (25-45\%) with average height of 18.56 $\mathrm{cm}$ and height MAI of $0.84 \mathrm{~m} /$ year (Table 3). Similar to the result on diameter, the lowest growth in height occurred in S. leprosula stand with planting distance of $2 \times 2 \mathrm{~m}$ and slope class of slightly sloping (8-15\%) with average height of $13.81 \mathrm{~m}$ and MAI of height $0.63 \mathrm{~m} /$ year. This is probably due to the difference in microsite because height growth is sensitive to difference in environmental quality (Malimbwi et al. 1992). There is also possibility that this is due to competition between plant individuals which can affect height growth at planting distance which are progressively denser (Zahabu et al. 2015). A study by Na'iem dan Faridah (2006) showed that S. leprosula had diameter Mean Annual Increment (MAI) of 0.75$1.2 \mathrm{~cm} /$ year. The low value of MAI is likely due to the lack of adaptation of the plant toward the environment 
(Pamoengkas and Prasetia 2014). Newman et al. (1996) stated that S. leprosula grows fast up to age of 20 years, but afterward being surpassed by other dipterocarp species.

\section{The distribution of diameter size of Shorea leprosula stands}

Data on the diameter of $S$. leprosula stands at various planting distances and slope classes are described in boxplot (Figure 2), so that their distribution and symmetry could be investigated. In the boxplot, the length of box (range box) in the diagram shows the level of data distribution and is also used to assess the symmetry of the data (Junaidi 2014). The results of boxplot diagram show that the stand with planting distance of $3 \times 3 \mathrm{~m}$ and slope class of very steep ( $>45 \%)$ exhibits normal distribution of diameter size, resembling the diameter distribution in plantation forest (Figure 2). Stand with normal distribution has symmetric pattern of diameter size where most of the tree diameters are distributed more around the central value, so that if they are visualized in the form of histogram graph, they will form a curve with the shape of a bell as stated by Pamoengkas and Prasetia (2014). The normal distribution of diameter size can indicate that the stand growth is able to adapt to the environment because it is in accordance with the characteristics of even-aged. On the other hand, the non-normal distribution implies that the stand is not well-adapted to the environment as there is competition among plants within the stand.

On the other hand, the distribution of diameter size in other slope classes and planting distances exhibits nonnormal manner because data distribution is not symmetric, where the median line is not in the center of the box and the whiskers (the extension lines of the box) do not have the same length (Figure 2). Non-normal distribution of diameter size indicates that population distribution of the stand tends to be above or below the value of their mean diameter. The non-normal distribution of diameter is probably due to lack of intensive silviculture maintenance in the S. leprosula research plot, such as pruning or thinning of the trees, and such condition could result in competition among the plants for nutrients and light. This phenomenon is likely due to the fact that the Research Forest is aimed largely to provide environmental services, mainly for research, so that there was no intensive silvicultural maintenance, resulting in less optimal growth of S. leprosula.

The largest variability of diameter data (Figure 2) occurs in stand with the longest boxplot width, namely in stand with planting distance of $4 \times 6 \mathrm{~m}$ and slope class of very steep $(>45 \%)$. The population of $S$. leprosula in this stand has diameter values largely distributed below their mean value, indicating that the tree population with smaller diameter were found more common in the plot. On the other hand, the lowest variability of diameter data occurred in stand with the shortest boxplot, namely in stand with planting distance of $2 \times 2 \mathrm{~m}$ and slope class of slightly sloping $(8-<15 \%)$, indicating that this stand is relatively uniform in term of diameter size. S. leprosula population in that stand had diameter values largely distributed above their mean, indicating that trees with larger diameter were more commonly found in the plot. According to Junaidi (2014), the wider or lengthier the boxplot size, the more variable are the data occurring inside the boxplot. The circle outside the boxplot is an outlier. The position of outliers at the top of the boxplot that had a longer top whisker indicates that the tree population is dominated by trees with large diameter. Conversely, if the circle (outlier) at the bottom of the boxplot that had a longer lower whisker, this indicates that the distribution of tree diameter tends to be small (Figure 2).

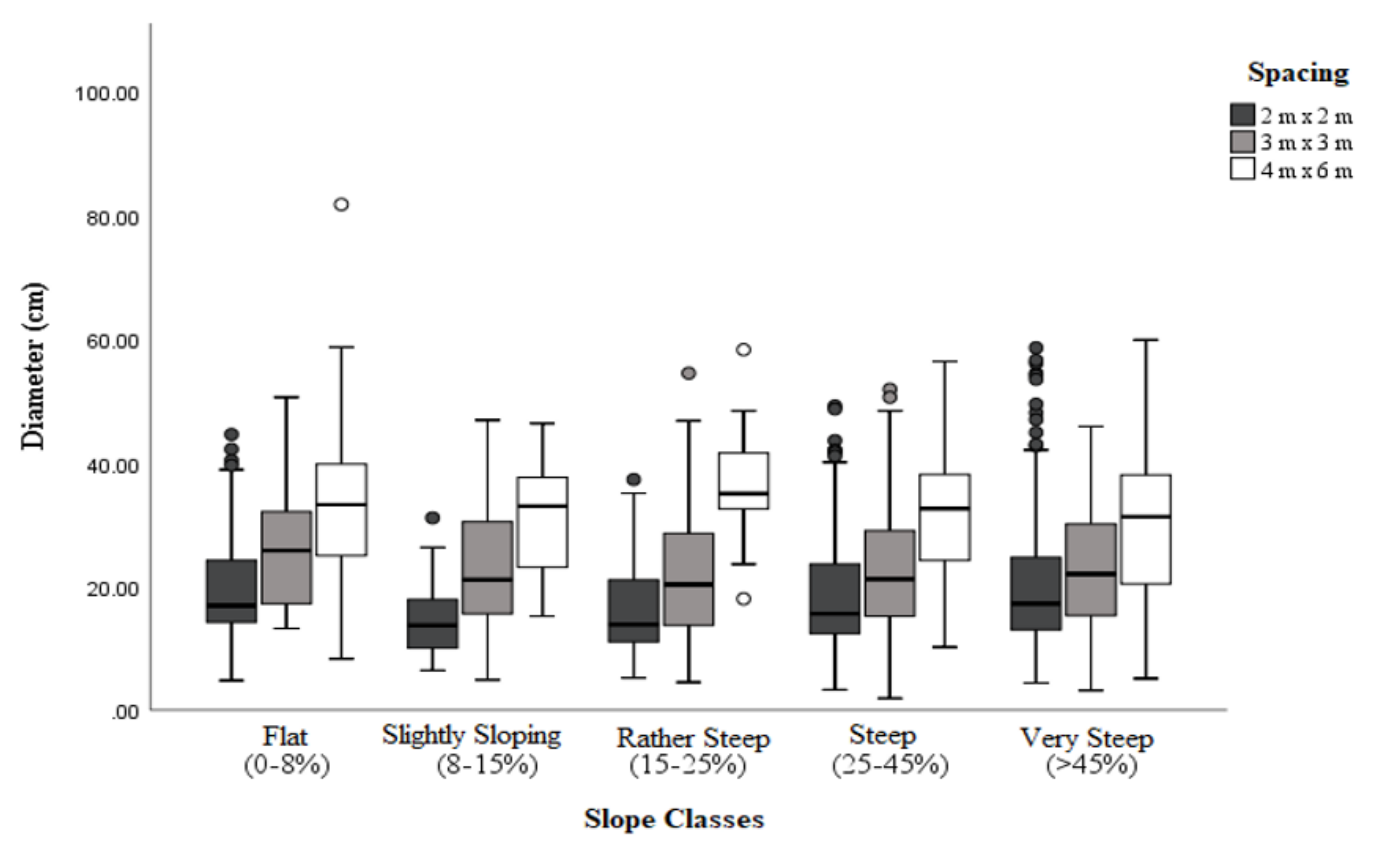

Figure 2. Boxplot diagram of Shorea leprosula diameter distribution at various planting distances and slope classes plantation. 
Competition among plants for survival and growth in each plot is seen through the presence of more plants with smaller and larger diameter. In relation to silviculture, there is a need for more intensive maintenance for the stand-in each plot to reduce competition between plant individuals. Silvicultural treatment, such as maintenance (tending) which creates horizontal or vertical liberation could reduce competition and provide more growing space to each individual so that sunlight can be utilized more optimally for plant growth (Pamoengkas 2010). Species which need sunlight to grow such as meranti (Shorea spp.) exhibits better growth with thinning silvicultural treatment, which could provide better-growing space by eliminating nearby competitor trees (Krisnawati and Wahjono 2010). Wistara et al. (2016) explained further that thinning can increase tree spacing and reduce competition for light, nutrition, and mineral, which can stimulate the growth of red meranti trees.

\section{The distribution of height of Shorea leprosula stands}

The distribution of height data of $S$. leprosula at various planting distances and slope classes is shown in boxplot in Figure 3. The boxplot shows that overall the height of $S$. leprosula is distributed asymmetrically. The stands that approach symmetrically data distribution (normal) are stand with planting distance of $3 \times 3 \mathrm{~m}$ and flat slope class $(0-<8 \%)$ and slightly sloping class $(8-<15 \%)$; and stand with planting distance of $4 \times 6 \mathrm{~m}$ with slope class of very steep $(>45 \%)$. The highest variability of plant height occurs in plot with planting distance of $2 \times 2 \mathrm{~m}$ and flat slope class $(0-8 \%)$. In relation to the tree height, if the presence of outliers at the top of the boxplot that had a longer top whisker indicates that the tree height data tends to have a larger height. Conversely, if outlier at the bottom of the boxplot is accompanied by a longer lower whisker, it showed that the tree height data distribution tends to have a smaller height. While, if outliers that are not followed by a longer whisker mean that they just only outliers, which has a very different value from the other numbers in the data.

The population of $S$. leprosula in the plot has plant height data which are distributed more above their mean value, indicating that trees with greater height were more commonly found. On the other hand, the lowest variability of height data occurs in plot with planting distance of $4 \times 6$ $\mathrm{m}$ and slope class of rather steep $(15-<25 \%)$. The population of $S$. leprosula in that stand possesses plant height data which are distributed more below their mean value, indicating that trees with small height were more commonly found, and beyond this, there are two outliers. Sadono and Silalahi (2010) explained that trees which are taller than the average height receive lower level of crown competition as compared to trees with height smaller than tree average, so that more sunlight intensity can be used for photosynthesis activity.

\section{Effect of planting distance and slope on the diameter and height of Shorea leprosula}

The results of ANOVA in Table 3 show that planting distance has significant effect on diameter and height growth (P-value $<0.05)$. Slope has significant effect on plant height, but not on plant diameter (P-value >0.05). Meanwhile, the interaction between planting distance and slope significantly affects diameter and height ( $\mathrm{P}$-value < $0.05)$.

Table 3. ANOVA of the effects of planting distance and slope on the diameter and height of Shorea leprosula

\begin{tabular}{lcc}
\hline \multicolumn{1}{c}{ Factor } & Diameter & Height \\
\hline Planting distance & $0.000^{*}$ & $0.000^{*}$ \\
Slope & $0.172^{\text {ns }}$ & $0.000^{*}$ \\
Planting distance $x$ slope & $0.000^{*}$ & $0.000^{*}$ \\
\hline
\end{tabular}

Notes: $*=$ treatments have significant effect at confidence interval of $95 \%$; ns $=$ treatments have no significant effect at confidence interval of $95 \%$.

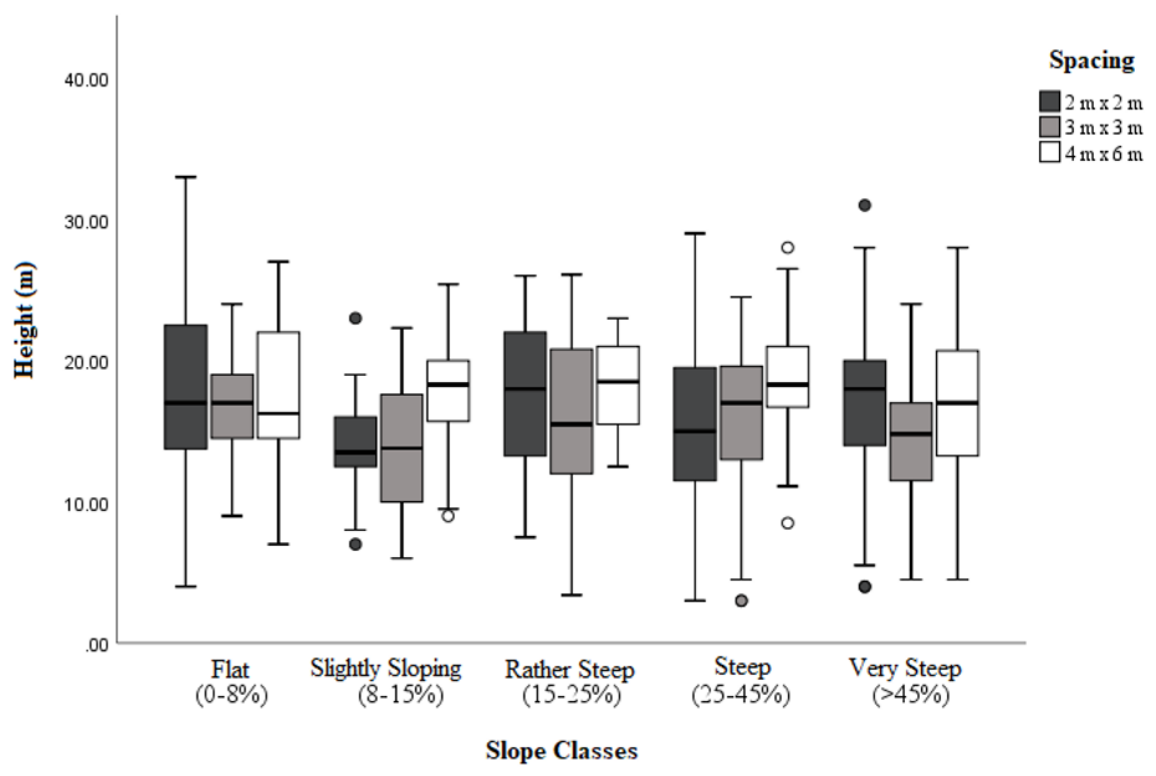

Figure 3. Boxplot diagram of height distribution of Shorea leprosula at various planting distances and slope classes 
The results of Duncan advanced test as presented in Table 5 shows that the effect of planting distance on the growth of $S$. leprosula is the highest in plot with planting distance of $4 \times 6 \mathrm{~m}$ as indicated with the highest average diameter and height of the plants. The lowest average diameter is exhibited in stand with planting distance of $2 \times 2$ $\mathrm{m}$, whereas the lowest average height is exhibited in stand with planting distance of $3 \times 3 \mathrm{~m}$. Subiakto et al. (2016) explained that the determination of planting distance depends on the objective of the forest utilization; i.e. planting dipterocarps at wider planting distance could produce greater diameter so that it is suitable to be adopted to fulfill the demand for wood aimed for construction and furniture. On the other hand, planting dipterocarps at shorter planting distance could produce denser population which is suitable for carbon stock and pulp industry because it produces higher volume/ha with smaller diameter. Based on this research (Table 4), planting of $S$. leprosula at the planting distance of $2 \times 2 \mathrm{~m}$ is suitable to be applied in forest with the purpose for carbon stock and pulp industry, whereas planting of $S$. leprosula with planting distance of $4 \times 6 \mathrm{~m}$ is suitable for plantation forestry to produce construction and furniture wood.

Results of advanced Duncan test in Table 5 show that slope has effect only on height growth. In relation to this, it is likely that the diameter growth of S. leprosula is affected more by other biotic and abiotic factors, rather than by slope factor. Height growth of S. leprosula at slope class of flat $(0-<8 \%)$ shows better results as compared with other four slope classes. On the other hand, the lowest average height growth is exhibited by slope class of slightly sloping $(8-<15 \%)$.

Wati (2008) found that the growth of S. leprosula at the age of 1-7 year in slope class flat $(0-8 \%)$ exhibited better results compared to the slope classes of $8-15 \%$ and 15 $25 \%$. Several factors could stimulate better growth in flat area, among others, is that soil properties in slope class of $0-8 \%$ had thick solum and good capacity to hold water. . It is explained further by Scharnweber et al. (2011) that lands with steep slope often have poorer soil nutrients and smaller availability of soil water, in which such factors could affect diameter and height growth of the plants.

Besides soil properties, other factors could affect $S$. leprosula growth in various slope classes, including light intensity being received by plants at each slope class. The semi tolerant character of $S$. leprosula makes this species requires more sunlight when the plants have reached large size (Erizilina et al. 2019). According to Wijayanto and Nurunnajah (2012), at micro-scale, slope direction (i.e. aspect) will determine greatly the amount of radiation received by the plants. Slope and slope direction constitute factors which could affect light acceptance for height and diameter growth of the trees and forest productivity (Saremi et al. 2014; Kravkaz et al. 2018; Balazy et al. 2019; Long et al. 2020). Large growth in height at slope class of flat (Table 5) could also probably due to slope direction which is better in obtaining sunlight for $S$. leprosula to grow.
Results of advanced Duncan test of the effect of interaction between planting distance and slope on the growth of $S$. leprsoula are shown in Table 6. The results suggest that in general, the interaction between planting distance of $4 \times 6 \mathrm{~m}$ and slope class rather steep $(25-<45 \%)$ produced better growth of $S$. leprosula compared to other interactions, because it exhibits larger average diameter $(35.99 \mathrm{~cm})$ and height $(18.56 \mathrm{~m})$.

Table 4. The results of advanced Duncan test of the effect of planting distance on diameter and height of Shorea leprosula

\begin{tabular}{ccc}
\hline $\begin{array}{c}\text { Planting } \\
\text { distance }\end{array}$ & $\begin{array}{c}\text { Diameter } \\
(\mathbf{c m})\end{array}$ & $\begin{array}{c}\text { Height } \\
(\mathbf{m})\end{array}$ \\
\hline $2 \mathrm{~m} \times 2 \mathrm{~m}$ & $18.83 \pm 8.99 \mathrm{c}$ & $16.57 \pm 5.26 \mathrm{~b}$ \\
$3 \mathrm{~m} \times 3 \mathrm{~m}$ & $22.77 \pm 9.91 \mathrm{~b}$ & $15.00 \pm 4.67 \mathrm{c}$ \\
$4 \mathrm{~m} \times 6 \mathrm{~m}$ & $31.32 \pm 11.25 \mathrm{a}$ & $17.35 \pm 4.79 \mathrm{a}$ \\
\hline
\end{tabular}

Notes: Values within same column followed by the same letters show that treatments have no significant effect at confidence interval of $95 \%$

Table 5. Results of advanced Duncan test of the effect of slope and diameter and height of Shorea leprosula

\begin{tabular}{lll}
\hline $\begin{array}{l}\text { Slope } \\
\text { classes }\end{array}$ & $\begin{array}{l}\text { Diameter } \\
(\mathbf{c m})\end{array}$ & $\begin{array}{l}\text { Plant height } \\
(\mathbf{m})\end{array}$ \\
\hline Flat & $22.73 \pm 11.60$ & $17.91 \pm 6.13 \mathrm{a}$ \\
Slightly sloping & $23.35 \pm 10.62$ & $14.84 \pm 4.33 \mathrm{~d}$ \\
Rather steep & $21.41 \pm 10.66$ & $16.81 \pm 5.23 \mathrm{~b}$ \\
Steep & $20.69 \pm 9.94$ & $15.37 \pm 4.99 \mathrm{c}$ \\
Very steep & $22.91 \pm 10.85$ & $16.31 \pm 4.89 \mathrm{bc}$ \\
\hline
\end{tabular}

Notes: Values within same column followed by the same letters show that treatments have no significant effect with confidence interval of $95 \%$

Table 6. Results of advanced Duncan test of the effect of interaction between planting distance and slope on diameter and height of Shorea leprosula

\begin{tabular}{llll}
\hline Slope class & $\begin{array}{l}\text { Planting } \\
\text { distance }\end{array}$ & $\begin{array}{l}\text { Diameter } \\
(\mathbf{c m})\end{array}$ & $\begin{array}{l}\text { Plant height } \\
(\mathbf{m})\end{array}$ \\
\hline Flat & $2 \mathrm{~m} \times 2 \mathrm{~m}$ & $19.42 \pm 8.42 \mathrm{def}$ & $18.13 \pm 6.42 \mathrm{ab}$ \\
Flat & $3 \mathrm{~m} \times 3 \mathrm{~m}$ & $27.36 \pm 13.10 \mathrm{c}$ & $16.38 \pm 4.31 \mathrm{abcd}$ \\
Flat & $4 \mathrm{~m} \times 6 \mathrm{~m}$ & $33.85 \pm 14.33 \mathrm{ab}$ & $17.72 \pm 5.65 \mathrm{abc}$ \\
Slightly sloping & $2 \mathrm{~m} \times 2 \mathrm{~m}$ & $14.47 \pm 5.86 \mathrm{~g}$ & $13.81 \pm 3.29 \mathrm{f}$ \\
Slightly sloping & $3 \mathrm{~m} \times 3 \mathrm{~m}$ & $23.38 \pm 9.92 \mathrm{~d}$ & $13.91 \pm 4.26 \mathrm{ef}$ \\
Slightly sloping & $4 \mathrm{~m} \times 6 \mathrm{~m}$ & $31.27 \pm 9.18 \mathrm{~b}$ & $17.81 \pm 4.01 \mathrm{ab}$ \\
Rather steep & $2 \mathrm{~m} \times 2 \mathrm{~m}$ & $16.46 \pm 7.35 \mathrm{fg}$ & $17.50 \pm 5.11 \mathrm{abcd}$ \\
Rather steep & $3 \mathrm{~m} \times 3 \mathrm{~m}$ & $22.11 \pm 10.19 \mathrm{de}$ & $15.96 \pm 5.57 \mathrm{bcd}$ \\
Rather steep & $4 \mathrm{~m} \times 6 \mathrm{~m}$ & $35.99 \pm 8.49 \mathrm{a}$ & $18.16 \pm 3.11 \mathrm{ab}$ \\
Steep & $2 \mathrm{~m} \times 2 \mathrm{~m}$ & $18.48 \pm 8.74 \mathrm{ef}$ & $15.35 \pm 5.13 \mathrm{def}$ \\
Steep & $3 \mathrm{~m} \times 3 \mathrm{~m}$ & $22.40 \pm 9.98 \mathrm{de}$ & $15.83 \pm 4.67 \mathrm{cdef}$ \\
Steep & $4 \mathrm{~m} \times 6 \mathrm{~m}$ & $32.29 \pm 9.96 \mathrm{ab}$ & $18.56 \pm 4.22 \mathrm{a}$ \\
Very steep & $2 \mathrm{~m} \times 2 \mathrm{~m}$ & $19.80 \pm 9.65 \mathrm{def}$ & $17.10 \pm 4.91 \mathrm{abcd}$ \\
Very steep & $3 \mathrm{~m} \times 3 \mathrm{~m}$ & $22.91 \pm 9.48 \mathrm{~d}$ & $14.15 \pm 4.026 \mathrm{ef}$ \\
Very steep & $4 \mathrm{~m} \times 6 \mathrm{~m}$ & $30.07 \pm 11.53 \mathrm{bc}$ & $16.84 \pm 5.05 \mathrm{abcd}$ \\
\hline
\end{tabular}

Notes: Values within same column followed by the same letters show that treatments have no significant effect with confidence interval of $95 \%$ 
On the other hand, interaction between planting distance $2 \times 2 \mathrm{~m}$ and slope class of slightly sloping (8$<15 \%$ ) exhibits the lowest growth of $S$. leprosula compared to other interactions, because it shows the lowest average diameter $(14.47 \mathrm{~cm})$ and height $(13.81 \mathrm{~m}$. In general, the best growth of $S$. leprosula is at the stand with planting distance of $4 \times 6 \mathrm{~m}$, and the stands can grow well at various slope classes. Soekotjo (2009) explained that S. leprosula preferred growth site with good drainage and on land with slope ranging from relatively slightly sloping to steep, and do not prefer growth site with water inundation. If compared with results of research by Budi et al. (2012) on the basis of natural distribution of $S$. laevis dan $S$. leprosula, it is known that $S$. laevis grow well in hill slope, whereas $S$. leprosula grow well in hill valley. This is because the plant requires soil condition with considerably good permeability so that it occupies the slope part of the hill.

In conclusion, the growth in diameter and height of $S$. leprosula is influenced by spacing. Spacing of $4 \times 6 \mathrm{~m}$ produced better growth than other planting distances with the largest increment for diameter and height with 1.49 $\mathrm{cm} /$ year and $0.82 \mathrm{~m} /$ year, respectively. The slope factor did not affect the diameter growth, but it did affect the height growth of $S$. leprosula. The flat slope class (0-8\%) has better $S$. leprosula height growth than other slope classes with a high increment value of $0.81 \mathrm{~m} /$ year. The interaction between the spacing of $4 \times 6 \mathrm{~m}$ and the slightly steep slope class $(15-25 \%)$ resulted in better diameter growth than other interactions with diameter increment of $1.64 \mathrm{~cm} /$ year. The interaction between the spacing of $4 \times 6 \mathrm{~m}$ and the steep slope class $(25-45 \%)$ resulted in better height growth compared to other interactions with increment of 0.83 $\mathrm{m} /$ year.

\section{ACKNOWLEDGEMENTS}

The authors wish to express an appreciation to project collaboration between FORDIA-KOMATSU for funding and supporting us during the experiment. We also would like to thank Forest Research and Development for allowing and facilitating this research.

\section{REFERENCES}

Adams HD, Kolbs TE. 2005. Tree growth response to drought and temperature in a mountain landscape in Northern Arizona, USA. J. Biogeogr 32: 1629-1640.

Adjers GA, Hadengganan S, Kuusipalo J, Nuryanto K, Vesa L. 1995. Enrichment planting of dipterocarps in logged-over secondary forests: effect of width, direction and maintenance method of planting line on selected Shorea species. For Ecol Manage 73 (1): 259-270.

Budi SW. Siregar IZ, Siregar UJ, Sukendro A, Pamoengkas P, Yunanto T. 2012. Rarity status and habitat of Shorea laevis and Shorea leprosula in Muara Teweh, Central Kalimantan. Jurnal Managemen Hutan Tropika 18 (2): 86-93. DOI: 10.7226/jtfm.18.2.86.

Bałazy R, Kaminska A, Ciesielski M, Socha J, Pierzchalski M. 2019. Modeling the effect of environmental and topographic variables affecting the height increment of Norway Spruce Stands in mountainous conditions with the use of LiDAR Data. Remote Sens. 11: 2407 .

Baumgartner RJ. 2019. Sustainable development goals and the forest sector- a complex relationship. Forests 10 (2): 152. DOI: 10.3390/f10020152

Davis LS, Jhonson KN. 1987. Forest Management. Mc Graw-Hill Book Company, New York.

Erizilina E, Pamoengkas P, Darwo. 2019. Hubungan sifat fisik dan kimia tanah dengan pertumbuhan meranti merah di KHDTK Haurbentes. Jurnal Pengelolaan Sumberdaya Alam dan Lingkungan 9 (1): 68-74. [Indonesian]

Gersonde RF, O'Hara KL. 2005. Comparative tree growth efficiency in Sierra Nevada mixed-conifer forests. Forest Ecol Manag. 219: 95108.

Junaidi. 2014. Deskripsi Data Melalui Box-Plot. Universitas Jambi, Jambi. [Indonesian]

Kafabih F. 2017. Penentuan kualitas tempat tumbuh sengon (Paraserianthes falcataria (1.) Nielsen ) pada areal IUPHHKHTI Trans PT Belantara Subur Kalimantan Timur [Hon. Thesis]. Institut Pertanian Bogor, Bogor. [Indonesian]

Kravkaz KIS, Sariyildiz T, Cetin M, Yigit N, Sevik H, Savaci G. 2018. Evaluation of the soil properties and primary forest tree species in Taskopru (Kastamonu) district. Fresenius Environ Bull 27 (3): 16131617.

KLHK [Kementian Lingkungan Hidup dan Kehutanan]. 2013. Berita KLHK: Hutan Penelitian Gunung Dahu. Puslitbanghut, Kementian Lingkungan Hidup dan Kehutanan, Bogor. http://puslitbanghut.or.id/index.php/page/hutan-penelitian-gunungdahu. [Indonesian]

KLHK [Kementerian Lingkungan Hidup dan Kehutanan]. 2020a. Hutan dan Deforestasi Indonesia Tahun 2019. Kementerian Lingkungan Hidup dan Kehutanan, Jakarta. http://ppid.menlhk.go.id/siaran_pers/browse/2435 [Indonesian]

KLHK [Kementerian Lingkungan Hidup dan Kehutanan]. 2020b. KLHK Tingkatkan Rehabilitasi Hutan dan Lahan Sepuluh Kali Lipat di 2019. Kementerian Lingkungan Hidup dan Kehutanan, Bogor. http://ppid.menlhk.go.id/siaran_pers/browse/1723 [Indonesian]

Krisnawati H, Wahjono D. 2010. Effect of post-logging silvicultural treatment on growth rates of residual stand in a tropical forest. J For Res 7 (2): 112-124.

Leksono B. 2010. Informasi sumber benih, bio-teknologi dan pemuliaan jenis-jenis prioritas HHBK FEM. Balai Besar Penelitian dan Pengembangan Bioteknologi dan Pemuliaan Tanaman Hutan, Yogyakarta. [Indonesian]

Long S, Zeng S, Liu F, Wang G. 2020. Influence of slope, aspect and competition index on the height-diameter relationship of Cyclobalanopsis glauca trees for improving prediction of height in mixed forests. Silva Fennica 54 (1): 10242. DOI: 10.14214/sf.10242.

Magalhães WM, Macedo RLG, Venturin N, Higashikawa EM, Júnior MY. 2007. Desempenho silvicultural de clones e espécies/procedências de Eucalyptus na região noroeste de Minas Gerais. Revista Cerne 13: 368-375.

Malimbwi RE, Persson A, Iddi S, Chamshama SAO, Mwihomeke ST. 1992. Effects of spacing on yield and some wood properties of Pinus patula at Rongai, Northern Tanzania. For Ecol Manag 53: 1-4.

Mawazin M, Suhaendi H. 2012. Pengaruh jarak tanam terhadap diameter Shorea leprosula Miq. umur lima tahun. Jurnal Penelitian Hutan dan Konservasi Alam 9 (2): 189-197. [Indonesian]

Na'iem M, Faridah E. 2006. Model of Intensive Enrichment Planting (TPTII). In: Rimbawanto A. (ed.). Silviculture Systems of Indonesia's Dipterocarps Forest Management A Lesson Learned. UGM, Yogyakarta.

Newman MF, Burges PF, Whitmore TC. 1996. Manual of Dipterocarps for Forester: Borneo Island Light Hardwoods, Anisoptera, Parashorea, Shorea (Red, White and Yellow Meranti). Cifor, Bogor.

Nugraheni D. 2012. Kinerja keuangan daerah, infrastruktur, dan kemiskinan: analisis Kabupaten/Kota di Indonesia 2006-1009 [Hon. Thesis]. Institut Pertanian Bogor, Bogor. [Indonesian]

Pamoengkas P. 2010. Analisis Pertumbuhan Tanaman dalam Sistem Silvikultur Tebang Pilih Tanam Jalur (TPTJ) di Areal IUPHHK-HA PT. SARPATIM, Kalimantan Tengah. Bagian Silvikultur. Fakultas Kehutanan IPB. Institut Pertanian Bogor, Bogor. [Indonesian]

Pamoengkas P, Prasetia R. 2014. Pertumbuhan meranti merah (Shorea leprosula Miq.) dalam sistem tebang pilih tanam jalur di areal IUPHHK-HA PT. Sarpatim, Kalimantan Tengah. Jurnal Silvikultur Tropika 5 (3): 174-180. [Indonesian] 
Purnomo S, Na'iem M, Hardiwinoto S. 2013. The Growth of Selected Shorea Spp in Secondary Tropical Rain Forest: The Effect of Silviculture Treatment to Improve Growth Quality of Shorea Spp. Procedia Environ Sci 17: 160-166.

Sadono R, Silalahi ML. 2010. Penentuan tingkat kompetisi tajuk tegakan jati hasil uji keturunan umur 11 tahun di KPH Ngawi. Jurnal Ilmu Kehutanan 4 (2): 80-86. [Indonesian]

Saremi H, Kumar L, Turner R, Stone C, Melville G. 2014. Impact of local slope and aspect assessed from LiDAR records on tree diameter in radiata pine (Pinus radiata D. Don) plantations. Ann For Sci 71 (7): 771-780. DOI: 10.1007/s13595-014-0374-4ff. ffhal-01102800.

Scharnweber T, Manthey M, Criegee C, Bauwe A, Schroder C, Wilmking M. 2011. Drought matters-declining precipitation influences growth of Fagus sylvatica L. and Quercus robur L. in north-eastern Germany. For Ecol Manag 262 (6): 947-961.

Schmidt S, Tresch S, Meusburger K. 2019. Modification of the RUSLE slope length and steepness factor (LS-factor) based on rainfall experiments at steep alpine grasslands. Methods 6: 219-229.

Soekotjo. 2009. Teknik Silvikultur Intensif (SILIN). Gadjah Mada University Press, Yogyakarta. [Indonesian]

Subiakto A, Rachmat HH, Sakai C. 2016. Choosing native tree species for establishing man-made forest: A new perspective for sustainable forest management in changing world. Biodiversitas 17 (2): 620625.

Wati NH. 2008. Pertumbuhan Shorea leprosula Miq dan Shorea parvifolia Dyer dalam sistem silvikultur TPTI Intensif (studi kasus di Areal IUPHHK PT. Sari Bumi Kusuma Unit Sungai Seruyan Kalimantan Tengah) [Hon. Thesis]. Institut Pertanian Bogor, Bogor. [Indonesian]

Whitmore TC. 1988. Forest types and forest zonation. In: Earl of Cranbrook (ed.) Malaysia: Key Environments Series. Pergamon Press, Oxford.

Wijayanto N, Nurunnajah. 2012. Intensitas cahaya, suhu, kelembaban dan perakaran lateral mahoni (Swietenia macrophylla King.) di RPH Babakan Madang, BKPH Bogor, KPH Bogor. J.Silvikltur Tropika 3 (1): 8-13. [Indonesian]

Wistara NJ, Sukowati M, Pamoengkas P. 2016. The properties of red meranti wood (Shorea leprosula Miq.) from stand with thinning and shade-free gap treatments. J Indian Acad Wood Sci 13 (1): 21-32.

Zahabu E, Raphael T, Chamshama SAO, Iddi S, Malimbwi E. 2015. Effect of spacing regimes on growth, yield, and wood properties of Tectona grandis at Longuza Forest Plantation, Tanzania. Int $l J$ For tes 2015 (3): 1-6 